Animal Production and Environment

Received on: 18/07/2020

Accepted on: 15/07/2021

\title{
Whole-plant soybean ensiling with chitosan and homolactic microbial inoculant: fermentative profile, aerobic stability, and sheep intake and digestibility
}

Ensilagem de planta inteira de soja com quitosana e inoculante microbiano homolático: perfil fermentativo, estabilidade aeróbia e consumo e digestibilidade em ovinos

${ }^{1}$ Gandra, Jefferson Rodrigues

https://orcid.org/0000-0002-4134-5115

${ }^{2}$ Del Valle, Tiago Antônio

https://orcid.org/0000-0001-8093-7132

${ }^{1}$ Pause, Alzira Gabriela da Silva

https://orcid.org/0000-0002-9157-7862

${ }^{3}$ Pedrini, Cibeli Almeida

https://orcid.org/0000-0002-7530-5381

${ }^{3}$ Oliveira, Euclides Reuter de

https://orcid.org/0000-0001-6282-4855
${ }^{3}$ Oliveira, Kelly Mari Pires de

https://orcid.org/0000-0002-9897-7770

${ }^{3}$ Batista, Jamille Débora de Oliveira https://orcid.org/0000-0002-7686-0563

${ }^{3}$ Antonio, Giovani

https://orcid.org/0000-0001-6962-1102

${ }^{3}$ Noia, Isabelle Zocolaro

https://orcid.org/0000-0003-2896-9043

${ }^{3}$ Acosta, Anderson

https://orcid.org/0000-0002-3832-9544

${ }^{3}$ Goes, Rafael Henrique de Tonissi e

Buschinelli de

https://orcid.org/0000-0002-4744-0367

${ }^{1}$ Universidade Federal do Sul e Sudeste do Pará -UNIFESSPA, R. Maranhão, s/n - Centro, Xinguara, CEP: 68555-016, Marabá/PA, Brasil

${ }^{2}$ Universidade Federal de Santa Maria - UFSM, Campus Sede, Av. Roraima, 1000, CEP $97105-$ 900, Santa Maria/RS, Brasil

${ }^{3}$ Universidade Federal da Grande Dourados - UFGD, Rodovia Dourados/Itahum, Km 12, Dourados, CEP: 79825-070, Dourados/MS, Brazil

*Mail for correspondence: jeffersongandra@ unifesspa.edu.br

\section{ABSTRACT}

This study aimed to evaluate the effects of chitosan and homolactic microbial inoculant on fermentative losses, chemical composition, fermentative profile, and aerobic stability of whole-plant soybean silage (WPSS). Additionally, it was evaluated nutrients intake and digestibility of sheep fed increasing levels of WPSS. Thirty experimental silos were randomly allocated to one of the following treatments: 1) CON: control, WPSS without additives; 2) LPPA: WPSS with Lactobacillus plantarum and Pediococcus acidilactici; 
and 3) CHI: chitosan, WPSS with $5 \mathrm{~g} / \mathrm{kg}$ of chitosan. Ten male sheep were used to evaluate increasing dietary levels of WPSS: $0,200,400,600$, and $800 \mathrm{~g} / \mathrm{kg}$ of diet dry matter (DM). Additives increased silage lactic acid bacteria and decreased the count of mold and yeast, gas, and total losses. Silages treated with additives had lower $\mathrm{pH}, \mathrm{NH}_{3}-$ $\mathrm{N}$, and ethanol concentrations and higher lactic and propionic acids relative to $\mathrm{CON}$. LPPA-treated silos showed higher organic matter and non-fiber carbohydrates content than CHI-ones. Additives increased the aerobic stability of WPSS. The addition of WPSS in sheep diets linearly increased nutrients intake and digestibility. Chitosan and LPPA improve WPSS fermentation, aerobic stability, and nutritional value. The WPSS in substitution to Cynodon hay increases sheep feed intake and nutrients digestibility.

Keywords: fermentative losses, lactic acid, legume silage, neutral detergent fiber, silage $\mathrm{pH}$.

\section{RESUMO}

Este estudo objetivou avaliar os efeitos da adição de quitosana e inoculante homolático sobre as perdas fermentativas, composição química, perfil fermentativo e estabilidade aeróbia da silagem de planta inteira de soja (SPIS). Em adição, foi avaliado o consumo e a digestibilidade de nutrientes em ovinos alimentados com dietas contendo níveis crescentes de SPIS. Trinta silos experimentais foram aleatoriamente alocados a um dos seguintes tratamentos: 1) CON: controle, SPIS sem aditivos; 2) LPPA: SPIS com Lactobacillus plantarum e Pediococcus acidilactici; e 3) QUI: quitosana, SPIS com 5 $\mathrm{g} / \mathrm{kg}$ de quitosana. Dez ovinos machos foram usados para avaliar os níveis dietéticos de SPIS: 0, 200, 400, 600 e $800 \mathrm{~g} / \mathrm{kg}$ da matéria seca (MS). Os aditivos aumentaram a contagem de bactérias láticas e reduziram a contagem de fungos e leveduras e as perdas fermentativas totais da SPIS. Silagens tratadas com aditivos tiveram menores $\mathrm{pH}, \mathrm{N}-\mathrm{NH}_{3}$ e etanol e maiores concentrações de ácido lático e propiônico, quando comparadas ao tratamento controle. Silos tratados com LPPA apresentaram maiores teores de matéria orgânica e carboidratos não fibrosos do que aqueles do tratamento QUI. Os aditivos aumentaram a estabilidade aeróbia da SPIS. A adição de SPIS na dieta de ovinos aumentou linearmente o consumo e a digestibilidade dos nutrientes. Quitosana e inoculante microbiano homolático melhoram a fermentação, estabilidade aeróbia e o valor nutricional da SPIS. A substituição de feno de Cynodon por SIPS aumenta o consumo e a digestibilidade dos nutrientes em ovinos.

Palavras-chave: ácido lático, fibra em detergente neutro, perdas fermentativas, $\mathrm{pH}$ da silagem, silagem de leguminosa.

\section{Introduction}

Whole-plant soybean is rich in protein and vitamin and a promising green fodder source to feed ruminants (JAHANZAD et al., 2014). However, the soybean harvest is seasonal, highlighting the importance of conservation (NI et al., 2017). Ensiling is one of the most traditional conservation practices based on lactic acid fermentation under anaerobic conditions (MCDONALD et al., 1991). After oxygen uptake, lactic acid is produced during ensiling, using water-soluble carbohydrate (WSC) as the primary 
substrate (MUCK, 2010). However, whole-plant soybeans have a low level of dry matter (DM) and WSC, resulting in an unpleasant fermentation (NI et al., 2017).

Driehuis et al. (2001) evaluated microbial inoculants in ryegrass silage containing different bacteria. Lactobacillus plantarum and Pediococcus pentosaceus inoculation improved fermentation conditions. On the other hand, chitosan has been used as an additive in sugarcane silage (GANDRA et al., 2016; DEL VALLE et al., 2018). Gandra et al. (2018) studied chitosan addition in whole-plant soybean silage (WPSS) and observed an increased count of lactic acid bacteria and a positive effect on in vitro degradation. To the best of our knowledge, there is no study evaluating chitosan instead of microbial inoculant on WPSS fermentation, chemical composition, and aerobic stability. Therefore, we hypothesized that microbial inoculant or chitosan addition in WPSS reduces silage losses, increases lactic acid and DM degradation of silages.

Protes et al. (2018) evaluated wholeplant soybean silage in replacement to sorghum silage. Soybean silage provides the same animal performance, carcass traits, and economic benefit compared with the sorghum silage diet. Evaluating soybean addition in dairy cows' diets, instead of corn silage as a roughage source, Ghizzi et al. (2020) observed reduced feed intake and animal performance. However, our previous studies evidenced that WPSS has a considerable high in vitro NDF and DM degradation (GANDRA et al., 2018). Our second hypothesis is that increasing WPSS levels, instead of Cynodon hay, in sheep diets could increase feed intake and nutrients digestibility. The present study aimed to evaluate the effects of chitosan and homolactic microbial inoculant effects on fermentative losses, chemical composition, fermentative profile, and aerobic stability of WPSS. Additionally, we assessed the impact of increasing levels of WPSS in sheep diets on nutrients intake and digestibility.

\section{MATERIALS AND METHODS}

This trial was conducted between January and April 2018 at the Ruminant Nutrition Laboratory of the Federal University of Grande Dourados, Dourados - MS, Brazil

1 Harvesting, Treatments, and Ensiling

Soybean (cultivar GMX Cancheiro RR; GMX) was cultivated in an experimental farm divided in 30 locations within a 5ha plot until reaching the R6 stage at 105 d (COFFEY et al., 1995). Approximately $200 \mathrm{~kg}$ of soybeans from each location was manually harvested (ground level) and chopped to a theoretical cut of 10 $\mathrm{mm}$ using a stationary cutter.

Thirty experimental mini-silos (plastic buckets, $30 \mathrm{~cm}$ in height, and $30 \mathrm{~cm}$ in diameter) provided with Bunsen valves were randomly distributed. Sand $(2,000$ grams) was placed in the bottom of the experimental silos and separated from forage with a nylon mesh screen (500 $\mu \mathrm{m})$ to drain effluents. The additives were applied individually on the whole soybean plant assigned for each bucket to generate correct replications. Forage was added to the buckets at a compaction rate of $650 \mathrm{~kg} / \mathrm{m}^{3}$, and silos were sealed, weighed, and stored at room temperature $\left(26.2 \pm 1.3^{\circ} \mathrm{C}\right.$; mean $\left.\pm \mathrm{SD}\right)$ for $100 \mathrm{~d}$. 
Experimental treatments consisted of 1CON (no additives); 2- LPPA (2 g/t of fresh forage microbial inoculant, Bactosilo $^{\circledR}$ Master Tropical, Lallemand Animal Nutrition, Aparecida de Goiania, Brazil) and 3- CHI (5 g/kg of fresh forage chitosan). Microbial inoculant was composed of Lactobacillus plantarum $4.0 \times 10^{10} \mathrm{CFU} / \mathrm{g}+$ Pediococcus acidilactici $10^{10} \mathrm{CFU} / \mathrm{g}$. For LPPA treatment, the inoculant was diluted in water $(2 \mathrm{~g} / \mathrm{L})$ and sprayed on the forage, and in all silos, water was added in the same proportion as the LPPA. Chitosan presented the following technical specifications: an apparent density of $0.64 \mathrm{~g} / \mathrm{mL}, 2.0 \%$ of ash, 7.0 to $9.0 \mathrm{pH}$, viscosity $<200 \quad \mathrm{cPs}$, and deacetylation level of $95 \%$ (Polymar Industria e Cia. Imp. And Exp. LTDA, Fortaleza, Brazil). Chitosan was topdressed and hand-mixed with fresh forage before forage was added into the silos.

2 Microbiological Quality

At the time of opening the experimental silos, samples of 100 grams were collected from each silo in its intermediate layer. Ten grams from samples were diluted in sterilized sodium chloride solution $(0.9 \%, 90 \mathrm{~mL})$, and a serial dilution was performed. Microorganism counts were carried out in triplicate through decimal dilution series in plates with De Man, Rogosa, Sharpe agar for LAB (BRICEÑO \& MARTINEZ, 1995), nutrient agar for aerobic and anaerobic bacteria (48 $\mathrm{h}$ of incubation at $30^{\circ} \mathrm{C}$ ), and potato dextrose agar $\left(120 \mathrm{~h}\right.$ of incubation at $\left.26^{\circ} \mathrm{C}\right)$ for mold and yeast as described by Rabie et al. (1997). The absolute values were obtained as colony-forming units and then log-transformed.

\section{$3 \quad$ Fermentative losses}

Experimental silos were weighed to determine gas losses. Effluent losses were calculated based on the difference between the weight of silo assembly (plastic bucket, nylon screen, and sand layer) before the storage and weight of silo assembly after $100 \mathrm{~d}$.

Gas losses (GL), effluent losses (EL) and dry matter recovery (DMR) were calculated according to Jobim et al. (2007), as follows:

$$
G L\left(\frac{g}{k g} D M\right)=\frac{S W E(g)-S W O(g)}{D M E(k g)}
$$

in which: SWE is the silo weight at the ensiling, SWO is silo weight at the opening, and DME is total DM ensiled.

$$
\begin{array}{r}
E P\left(\frac{g}{k g} D M\right) \\
=\frac{W S A O(g)-W S A E(g)}{D M E(k g)}
\end{array}
$$

where: WSAO is the weight of silo assembly after the opening (g), and WSAE is the weight of silo before the ensiling $(\mathrm{g})$.

$$
D M R\left(\frac{g}{k g}\right)=\frac{D M O(g)}{D M E(k g)}
$$

In which: DMO is total DM after the opening of the silo $(\mathrm{kg})$, and DME is total DM before the ensiling $(\mathrm{kg})$.

\section{$4 \quad$ Fermentative Profile}

Silage juice was extracted from forage samples using a hydraulic press, and $\mathrm{pH}$ was measured using a digital potentiometer (LUCA-210 ${ }^{\circledR}$, Lucadema, Sao José do Rio Preto, Brazil). Silage juice aliquots $(2 \mathrm{~mL})$ were mixed with 1 $\mathrm{mL}$ of sulfuric acid $(1 N)$ for the determination of ammonia nitrogen concentration through the colorimetric method described by Foldager (1977). Organic fatty acids and ethanol were determined as reported by Del Valle et 
al. (2018). Briefly, aliquots (1 mL) of silage juice were mixed with formic acid $(0.2 \mathrm{~mL})$ in amber glass bottles and frozen until analysis. Volatile fatty acids and ethanol concentrations were determined in a gas chromatograph (Focus GC, Thermo Fisher Scientific Inc., Waltham, MA) equipped with an automatic sample injector (model AS3000, Thermo Fisher Scientific Inc.), a glass column $(2.0 \mathrm{~m} \times 0.5 \mathrm{~cm} \mathrm{80/120}$ Carbopack B-DA/4\% Carbowax 20M phase; Sigma-Aldrich, St. Louis, MO), and a flame ionization detector set at $270^{\circ} \mathrm{C}$. The chromatograph oven and injector temperatures were set to $190^{\circ} \mathrm{C}$ and $220^{\circ} \mathrm{C}$, respectively. Hydrogen was used as the carrier gas flowing at 30 $\mathrm{mL} / \mathrm{min}$. The lactic acid concentration was measured by HPLC (LC-10ADVP Shimadzu HPLC system, Shimadzu Inc., Kyoto, Japan), according to Ding et al. (1995).
5 Chemical Composition and In Vitro Degradation

Samples $(1,000 \mathrm{~g})$ of chopped soybean plant were assessed for contents of DM (method 950.15), ash (method 942.05), OM (DM - ash), CP $(\mathrm{N} \times 6.25$; method 984.13), and ether extract (EE; method 920.39) according to AOAC International (2000; Table 1). Non-fiber carbohydrate was calculated as NFC = $1,000-(\mathrm{NDF}+\mathrm{CP}+\mathrm{EE}+$ ash $)$, all values expressed as grams per kilogram of DM. Neutral detergent fiber (without sodium sulfite), ADF, and lignin (sulfuric acid method) were determined according to Van Soest et al. (1991). The net energy of lactation was estimated, according to NRC (2001). Silage buffering capacity was analyzed according to Playne and McDonald (1966), and the digestion method described by Miller (1998) was used to determine macro-minerals.

Table 1. Chemical composition of whole soybean plant before ensiling

\begin{tabular}{lr}
\hline Chemical composition, g/kg DM & \\
Dry matter, g/kg as fed & 394 \\
Organic matter & 911 \\
Neutral detergent fiber & 512 \\
Acid detergent fiber & 381 \\
Crude Protein & 210 \\
Non-fiber carbohydrate ${ }^{\dagger}$ & 191 \\
Ash & 88.7 \\
Lignin & 63.1 \\
Ether extract & 25.3 \\
Potassium & 17.0 \\
Calcium & 10.0 \\
Magnesium & 5.10 \\
Sulfur & 2.20 \\
Phosphor & 1.90 \\
NE $(\mathrm{MJ} / \mathrm{kg} \mathrm{DM})^{\dagger}$ & 5.74 \\
Buffering capacity, mEq/kg of DM & 527 \\
\hline
\end{tabular}


${ }^{\dagger}$ Estimated according to NRC (2001).

Dry matter and NDF in vitro digestibility were determined using filter bags and artificial rumen incubator (TE-150, Tecnal, Piracicaba, Brazil) according to Tilley and Terry (1963) and adapted by Holden (1999). Briefly, filter bags with samples were incubated for $48 \mathrm{~h}$ at $39^{\circ} \mathrm{C}$ in a buffer-inoculum solution $(1,600 \mathrm{~mL}$ of buffer solution and $400 \mathrm{~mL}$ of rumen inoculum). The rumen inoculum was obtained from two Jersey heifers, fed with corn silage ad libitum, and $2 \mathrm{~kg}$ of concentrate per day. Samples were performed before the morning fed, using a PCV probe. Jars containing the bufferinoculum solution were purged with $\mathrm{CO}_{2}$, and lids had gas relief valves. After the incubation period, the bufferinoculum was drained from the jars, and the filter bags were gently squeezed against the sides of the jar to remove the gas trapped in the inflated bags. Afterward, bags were rinsed in jars with three changes of warm tap water.

\section{$6 \quad$ Silage Aerobic Stability}

During the 6-d period of aerobic stability evaluation, silos were maintained at room temperature $(23.3 \pm 2.34$, mean \pm SD), and the temperature of WPSS was measured every eight hours after oxygen exposure using an infrared thermometer (MS6530, Wiltronics Research Pty. Ltd., Victoria, Australia). Besides, samples $(200 \mathrm{~g})$ from silos of each treatment were collected every $24 \mathrm{~h}$ to assess $\mathrm{pH}$ after silo oxygen exposure (Kung et al., 1984). The aerobic stability was defined as the period (h) in which WPSS temperature remained less than $1^{\circ} \mathrm{C}$ above the room temperature (DRIEHUIS et al., 2001).

7 In vivo nutrients intake and digestibility

Ten castrated lambs $(28.7 \pm 3.66 \mathrm{~kg}$ body weight and $6.4 \pm 0.3 \mathrm{mo}$ ) were assigned to a $5 \times 5$ Latin square design trial, consisting of 19-d periods, with the last $5 \mathrm{~d}$ for data record and sampling. Diet was formulated for $200 \mathrm{~g}$ average daily gain, using Small Ruminants Nutritional System (SRNS) (Table 2). Lambs within each square were randomly assigned to diets containing increasing levels of whole plant soybean silage in the total diet $(0,200,400,600$, and $800 \mathrm{~g} / \mathrm{kg}$ of DM). Silage was produced in $200 \mathrm{~L}$ tubs (3 tubs for each treatment). Silages were produced as previously described: microbial inoculant (Lactobacillus plantarum $4.0 \times 10^{10} \mathrm{CFU} / \mathrm{g}+$ Pediococcus acidilactici $10^{10} \mathrm{CFU} / \mathrm{g}$ ) was individually weighed (2 g/ton.), diluted in water, and manually mixed with whole-plant soybean silage. Animals were housed in metabolic cages and fed twice daily, at 07:00 and 13:00 $\mathrm{h}$, targeting refusals between $10 \%$ to $15 \%$. Samples of feeds and refusals were collected daily during the sampling period and pooled in a composite sample for subsequent chemical analyses.

Table 2. Ingredients and chemical composition of experimental diet

\begin{tabular}{lccccc}
\hline \multirow{2}{*}{ Item } & \multicolumn{5}{c}{ Experimental diets $^{\dagger}$} \\
\cline { 2 - 6 } & 0 & 200 & 400 & 600 & 800 \\
\hline Ingredients & 0.00 & 200 & 400 & 600 & 800 \\
Soybean silage & 800 & 600 & 400 & 200 & 0.00 \\
Cynodon hay & & & & &
\end{tabular}




\begin{tabular}{|c|c|c|c|c|c|}
\hline Ground corn & 31.5 & 59.1 & 104 & 118 & 160 \\
\hline Ground whole soybean & 121 & 96.1 & 50.8 & 41.8 & 0.00 \\
\hline Urea & 7.90 & 5.00 & 4.90 & 0.00 & 0.00 \\
\hline Mineral premix & 39.8 & 39.8 & 39.8 & 39.8 & 39.8 \\
\hline \multicolumn{6}{|c|}{ Chemical composition, g/kg DM } \\
\hline Dry matter, $\mathrm{g} / \mathrm{kg}$ as fed & 836 & 741 & 647 & 552 & 457 \\
\hline Organic matter & 927 & 921 & 917 & 912 & 910 \\
\hline Neutral detergent fiber & 617 & 548 & 476 & 410 & 338 \\
\hline Acid detergent fiber & 312 & 303 & 293 & 286 & 276 \\
\hline Crude Protein & 155 & 155 & 156 & 155 & 157 \\
\hline Non-fiber carbohydrate ${ }^{\S}$ & 14.5 & 21.4 & 29.0 & 35.6 & 42.9 \\
\hline Ether extract & 46.0 & 43.0 & 35.0 & 35.0 & 29.0 \\
\hline $\mathrm{NE}(\mathrm{MJ} / \mathrm{kg} \mathrm{DM})^{\S}$ & 2.89 & 3.22 & 3.48 & 3.85 & 4.10 \\
\hline
\end{tabular}

Increasing dietary levels of WPSS: 0, 200, 400, 600, and $800 \mathrm{~g} / \mathrm{kg} \mathrm{DM}$.

${ }^{\ddagger}$ Contained per kg of product: $120 \mathrm{~g} \mathrm{Ca}, 88.0 \mathrm{~g} \mathrm{P}, 75.0 \mathrm{mg} \mathrm{I}, 1,300 \mathrm{mg} \mathrm{Na}, 15.0 \mathrm{mg} \mathrm{Se}, 12.0 \mathrm{mg}$ $\mathrm{S}, 3,630 \mathrm{mg} \mathrm{Zn,} 55.5 \mathrm{mg} \mathrm{Co,} \mathrm{1,530} \mathrm{mg} \mathrm{Cu,} \mathrm{and} \mathrm{1,800} \mathrm{mg} \mathrm{Fe.}$

${ }^{\S}$ Estimated according to NRC (2001).

On days 16-18 of each experimental period, total fecal collections were performed through a metabolic cage device that separates urine from the feces. The feces were weighed every 24 hours of collection, and a $10 \%$ aliquot of each collection day was collected for further analysis of the digestibility of DM, CP, NDF, and EE. Samples of silages, dietary ingredients, refusals, and feces were analyzed for DM (method 950.15), crude protein $(\mathrm{CP}, \mathrm{N} \times 6.25$; Kjeldahl method 984.13), ether extract (EE; method 920.39) according to AOAC (2000) and neutral detergent fiber (without sodium sulfite), according to Van Soest et al. (1991). Nutrient digestibility $(\mathrm{NuD})$ was estimated as:

$$
\begin{aligned}
& N u D\left(\frac{g}{k g}\right) \\
& =\frac{N u_{\text {intake }}(g)-N u_{\text {Fecal }}(g)}{N u_{\text {intake }}(k g)}
\end{aligned}
$$

where $N u_{\text {intake }}$ is the nutrient intake and $N u_{\text {Fecal }}$ is the fecal nutrient excretion.

\section{$8 \quad$ Statistical Analysis}

Statistical analyses of silage evaluations were performed using PROC MIXED of SAS (SAS Institute Inc, 2011). Data from the silo experiment were analyzed using the following model:

$$
Y_{i j}=\mu+T_{i}+e_{i j}
$$

with $e_{i j} \approx N\left(0, \sigma_{e}^{2}\right)$, where: $Y_{i j}$ is the observed value; $\mu$ is the overall mean; $T_{i}$ is the fixed effect of treatment $(i=1,2$, and 3$) ; e_{i j}$ is the random residual error $(j$ $=1$ to 10); $N$ stands for Gaussian deviation; and $\sigma_{e}^{2}$ is the variance of error. The treatment effect was analyzed as orthogonal contrasts: (1) (LPPA + CHI) vs. CON, and (2) LPPA vs. CHI.

Data of nutrients intake and digestibility were analyzed according to the following model:

$$
Y_{i j k l}=\mu+S_{i}+a_{j: i}+T_{k}+P_{l}+e_{i j k l}
$$

with $a_{j: i} \approx N\left(0, \sigma_{a}^{2}\right) ; e_{i j k l} \approx N\left(0, \sigma_{e}^{2}\right)$, where: $Y_{i j k l}$ is the value of the dependent variable; $\mu$ is the overall mean; $S_{i}$ is the fixed effect of Latin Square ( $i=1$ and 2); $a_{j: i}$ is the random effect of $j^{\text {th }}$ animal within the $i^{\text {th }}$ Latin Square ( $j=1$ to 10 ); $T_{k}$ is the fixed effect of treatment $(k=1$, 
2, 3, 4 and 5); $P_{l}$ is the fixed effect of the experimental period $(l=1,2,3,4$ and 5); $e_{i j k l}$ is the random experimental error; $N$ stands for Gaussian deviation; $\sigma_{a}^{2}$ is the variance of animals; and $\sigma_{e}^{2}$ is the variance of error. The treatment effect was analyzed as a polynomial regression. The significance level of $5 \%$ was considered for all statistical analyses.

\section{Results}

The additives increased $(P \leq 0.033)$ lactic acid and aerobic bacteria and decreased $(P=0.001)$ the count of mold and yeast (Table 3). Also, silos containing additives had lower $(P \leq$ $0.044)$ gas and total losses, with higher $(P \leq 0.033)$ effluent losses and DM recovery, relative to CON silos. Between evaluated additives, $\mathrm{CHI}$ increased $(P \leq$ 0.012 ) counts of aerobic bacteria and mold and yeast, and did not affect $(P \geq$ $0.652)$ anaerobic and lactic acid bacteria count, compared to LPPA. Chitosan showed lower $(P \leq 0.042)$ gas and total losses, and higher $(P \leq 0.042) \mathrm{DM}$ recovery, than LPPA. There was no difference $(P \geq 0.342)$ among $\mathrm{CHI}$ and LPPA on effluent losses.

Table 3. Microbiology and fermentative losses of whole plant soybean silage treated with chitosan and homolactic microbial inoculant

\begin{tabular}{lrrrrrr}
\hline \multirow{2}{*}{ Item } & \multicolumn{3}{c}{ Trataments $^{\dagger}$} & \multirow{3}{*}{ SEM } & \multicolumn{3}{c}{$P^{\ddagger}$} \\
& COM & LPPA & CHI & & C1 & C2 \\
\hline Microbiology, $\log _{10}$ CFU/g & & & & & & \\
Aerobic bacteria & 5.95 & 6.69 & 8.32 & 0.153 & 0.001 & 0.003 \\
Anaerobic bacteria & 6.04 & 5.56 & 4.60 & 0.164 & 0.512 & 0.652 \\
Lactic bacteria & 6.61 & 8.36 & 7.89 & 0.101 & 0.033 & 0.653 \\
Mold and yeast & 6.89 & 4.54 & 5.00 & 0.112 & 0.001 & 0.012 \\
Fermentative losses & & & & & & \\
Gas, g/kg fresh matter & 22.2 & 13.7 & 10.9 & 0.203 & 0.044 & 0.001 \\
Gas, g/kg DM & 81.2 & 49.8 & 30.2 & 0.673 & 0.021 & 0.067 \\
Effluent, g/kg fresh matter & 3.69 & 4.21 & 4.09 & 0.311 & 0.033 & 0.342 \\
Effluent, g/kg DM & 3.40 & 4.00 & 3.80 & 0.174 & 0.010 & 0.563 \\
Total, g/kg DM & 84.7 & 53.8 & 34.0 & 0.32 & 0.001 & 0.042 \\
DM recovery, g/kg DM & 915 & 946 & 966 & 0.32 & 0.001 & 0.042 \\
\hline
\end{tabular}

${ }^{\dagger}$ Treatments: CON (Control), WPSS without additives; LPPA (Lactobacillus plantarum $4.0 \times 10^{10} \mathrm{CFU} / \mathrm{g}+$ Pediococcus acidilactici $\left.10^{10} \mathrm{CFU} / \mathrm{g}\right)$; $\mathrm{CHI}$ : chitosan, $5 \mathrm{~g} / \mathrm{kg}$ as-fed.

Probabilities: $\mathrm{C} 1$ : additives effect (CON vs LPPA+CHI); C2: comparison of additives (LPPA vs CHI).

Silages treated with additives had lower $(P \leq 0.021) \mathrm{pH}$ value, $\mathrm{NH}_{3}-\mathrm{N}$, and ethanol concentrations (Table 4). On the other hand, CHI and LPPA increased $(P$ $\leq 0$. 012) lactic, BCFA, and propionic acids, in relation to CON. Additionally, CHI-treated silos had higher $(P \leq 0.038)$
$\mathrm{NH}_{3}-\mathrm{N}$, ethanol, and acetic acid, compared to those silos of LPPA treatment. Treatments did not affect $(P \geq$ $0.234)$ silage butyric acid concentration. Additives supply in WPSS reduced $(P \leq$ 0.011 ) silage content of DM and EE, whereas increased the content of $\mathrm{CP}$ and 
Ca (Table 5). Concerning CHI, the supply of LPPA reduced $(P=0.021) \mathrm{Ca}$ and increased $(P \leq 0.032)$ silage content of OM and NFC. However, treatments showed no effects $(P \geq 0.606)$ on silage fiber content (NDF and ADF), as soon as the net energy content of WPSS. Although additives increased $(P=0.022)$ $\mathrm{NDF}$ in vitro degradation, treatments showed no effects $(P \geq 0.147)$ on DM in vitro degradation.

Table 4. Fermentative profile of whole plant soybean silage treated with chitosan and homolactic microbial inoculant

\begin{tabular}{|c|c|c|c|c|c|c|}
\hline \multirow{2}{*}{ Item } & \multicolumn{3}{|c|}{ Trataments $^{\dagger}$} & \multirow{2}{*}{ SEM } & \multicolumn{2}{|c|}{$P^{t}$} \\
\hline & $\mathrm{CON}$ & LPPA & $\mathrm{CHI}$ & & $\mathrm{C} 1$ & $\mathrm{C} 2$ \\
\hline $\mathrm{pH}$ & 3.55 & 3.46 & 3.45 & 0.011 & 0.003 & 0.687 \\
\hline $\mathrm{NH}_{3}-\mathrm{N}, \mathrm{g} / \mathrm{kg} \mathrm{N}$ & 82.6 & 75.3 & 80.7 & 0.65 & 0.002 & 0.001 \\
\hline Organic acids, $\mathrm{g}$ & & & & & & \\
\hline Lactic & 5.54 & 6.01 & 6.78 & 0.033 & 0.012 & 0.232 \\
\hline Ethanol & 0.723 & 0.493 & 0.566 & 0.082 & 0.021 & 0.038 \\
\hline Acetic & 1.40 & 1.28 & 1.82 & 0.015 & 0.372 & 0.004 \\
\hline Propyonic & 0.070 & 0.090 & 0.093 & 0.021 & 0.001 & 0.576 \\
\hline Butyric & 0.197 & 0.123 & 0.136 & 0.026 & 0.659 & 0.234 \\
\hline $\mathrm{BCFA}^{\S}$ & 0.216 & 0.278 & 0.296 & 0.088 & 0.001 & 0.354 \\
\hline
\end{tabular}

Treatments: CON (Control), WPSS without additives; LPPA (Lactobacillus plantarum $4.0 \times 10^{10} \mathrm{CFU} / \mathrm{g}+$ Pediococcus acidilactici $\left.10^{10} \mathrm{CFU} / \mathrm{g}\right)$; CHI: chitosan, 5 $\mathrm{g} / \mathrm{kg}$ as-fed.

Trobabilities: $\mathrm{C} 1$ : additives effect (CON vs LPPA+CHI); $\mathrm{C} 2$ : comparison of additives (LPPA vs CHI).

${ }^{\S}$ Branched-chain fatty acids.

Table 5. Chemical composition of whole plant soybean silage treated with chitosan and homolactic microbial inoculant

\begin{tabular}{|c|c|c|c|c|c|c|}
\hline \multirow{2}{*}{ Item } & \multicolumn{3}{|c|}{ Trataments $^{\dagger}$} & \multirow{2}{*}{ SEM } & \multicolumn{2}{|c|}{$P^{t}$} \\
\hline & $\mathrm{CON}$ & LPPA & $\mathrm{CHI}$ & & $\mathrm{C} 1$ & $\mathrm{C} 2$ \\
\hline \multicolumn{7}{|c|}{ Chemical composition, g/kg DM } \\
\hline Dry matter & 353 & 338 & 332 & 7.1 & $<0.001$ & 0.784 \\
\hline Organic matter & 927 & 931 & 926 & 1.0 & 0.650 & 0.004 \\
\hline Neutral detergent fiber & 401 & 406 & 404 & 2.7 & 0.887 & 0.885 \\
\hline Acid detergent fiber & 341 & 339 & 341 & 3.4 & 0.776 & 0.665 \\
\hline Crude protein & 179 & 198 & 194 & 2.6 & 0.011 & 0.342 \\
\hline Non-fiber carbohydrate & 352 & 350 & 341 & 7.4 & 0.543 & 0.032 \\
\hline Lignin & 63.5 & 63.6 & 65.6 & 1.26 & 0.432 & 0.776 \\
\hline Ether extract & 31.8 & 25.1 & 20.9 & 3.02 & 0.001 & 0.332 \\
\hline Potassium & 13.2 & 12.9 & 13.2 & 0.11 & 0.321 & 0.342 \\
\hline Calcium & 8.00 & 8.30 & 8.90 & 0.11 & 0.017 & 0.021 \\
\hline Magnesium & 4.40 & 4.40 & 4.34 & 0.11 & 0.654 & 0.340 \\
\hline Sulfur & 1.96 & 1.63 & 1.86 & 0.11 & 0.543 & 0.421 \\
\hline Phosphor & 2.28 & 2.48 & 2.47 & 0.12 & 0.876 & 0.760 \\
\hline $\mathrm{NE}, \mathrm{MJ} / \mathrm{kg} \mathrm{DM}^{\S}$ & 6.03 & 6.07 & 6.03 & 0.046 & 0.998 & 0.606 \\
\hline
\end{tabular}


In vitro degradation, $\mathrm{g} / \mathrm{kg}$

Dry matter

$641.2 \quad 648.5 \quad 647.6$

4.45

0.147

0.544

Neutral detergent fiber

$542.5 \quad 555.8 \quad 557.6$

3.41

0.022

0.484

†Treatments: CON (Control), WPSS without additives; LPPA (Lactobacillus plantarum $4.0 \times 10^{10} \mathrm{CFU} / \mathrm{g}+$ Pediococcus acidilactici $\left.10^{10} \mathrm{CFU} / \mathrm{g}\right) ; \mathrm{CHI}$ : chitosan, $5 \mathrm{~g} / \mathrm{kg}$ as-fed.

Probabilities: C1: additives effect (CON after aerobic exposure, compared to LPPA+CHI); C2: comparison of additives (LPP/CHI. The addition of WPSS in sheep $\mathrm{CHI})$.

${ }^{\S}$ Estimated according to NRC(2001). diets linearly increased $(P \leq 0.044) \mathrm{DM}$,

Additives increased $(P \leq 0.023)$ the time of aerobic stability and average $\mathrm{pH}$ after aerobic exposure (Table 6). Comparing additives, LPPA increased $(P=0.001)$ aerobic stability period and reduced $(P \leq$ 0.026 ) average $\mathrm{pH}$ and $\mathrm{DM}$ of silage

$\mathrm{OM}$, and $\mathrm{CP}$ intake and digestibility (Table 7). Although WPSS quadratically affected $(P=0.033)$ NDF intake, there was $(P=0.021)$ linear positive effect on NDF digestibility. Maximal NDF intake was observed using $389 \mathrm{~g} / \mathrm{kg} \mathrm{DM}$ of WPSS.

Table 6. Aerobic stability of whole plant soybean silage treated with chitosan and homolactic microbial inoculant

\begin{tabular}{|c|c|c|c|c|c|c|}
\hline \multirow{2}{*}{ Item } & \multicolumn{3}{|c|}{ Trataments $^{\dagger}$} & \multirow{2}{*}{ SEM } & \multicolumn{2}{|c|}{$P^{\ddagger}$} \\
\hline & $\mathrm{CON}$ & LPPA & CHI & & $\mathrm{C} 1$ & $\mathrm{C} 2$ \\
\hline Temperature, ${ }^{\circ} \mathrm{C}$ & & & & & & \\
\hline Maximun & 24.9 & 25.2 & 26.4 & 0.12 & 0.265 & 0.432 \\
\hline Sum (5 days) & 325 & 322 & 346 & 1.09 & 0.123 & 0.262 \\
\hline Average & 19.6 & 21.6 & 24.2 & 0.33 & 0.012 & 0.022 \\
\hline Time, $\mathrm{h}$ & & & & & & \\
\hline Stability & 46.2 & 110 & 77.8 & 1.07 & 0.002 & 0.001 \\
\hline $\mathrm{pH}$ & 3.86 & 3.67 & 4.21 & 0.442 & 0.023 & 0.001 \\
\hline Dry matter & 376 & 352 & 361 & 0.36 & 0.342 & 0.026 \\
\hline
\end{tabular}

†Treatments: CON (Control), WPSS without additives; LPPA (Lactobacillus plantarum $4.0 \times 10^{10} \mathrm{CFU} / \mathrm{g}+$ Pediococcus acidilactici $10^{10} \mathrm{CFU} / \mathrm{g}$ ); CHI: chitosan, 5 $\mathrm{g} / \mathrm{kg}$ as-fed.

Probabilities: $\mathrm{C} 1$ : additives effect (CON vs LPPA+CHI); $\mathrm{C} 2$ : comparison of additives (LPPA vs CHI).

Table 7. Nutrients intake and digestibility of finishing sheep fed with increasing levels of WPSS, replacing cynodon hay

\begin{tabular}{|c|c|c|c|c|c|c|c|c|}
\hline \multirow{2}{*}{ Item } & \multicolumn{5}{|c|}{ Experimental diets $^{\dagger}$} & \multirow{2}{*}{ SEM } & \multicolumn{2}{|r|}{$P^{\dagger}$} \\
\hline & 0 & 200 & 400 & 600 & 800 & & Linear & Quadratic \\
\hline Intake, $\mathrm{g} / \mathrm{d}$ & & & & & & & & \\
\hline Dry matter & 714 & 1052 & 1172 & 1285 & 1342 & 72 & 0.002 & 0.284 \\
\hline Organic matter & 662 & 967 & 1073 & 1168 & 1220 & 65 & 0.003 & 0.348 \\
\hline Crude protein & 111 & 163 & 183 & 198 & 210 & 11 & 0.014 & 0.541 \\
\hline Neutral detergent fiber & 441 & 575 & 557 & 525 & 453 & 26 & 0.321 & $0.033^{\S}$ \\
\hline
\end{tabular}




\begin{tabular}{lllllllll} 
Dry matter & 526 & 550 & 557 & 573 & 608 & 1.18 & 0.017 & 0.719 \\
Organic matter & 529 & 553 & 562 & 588 & 615 & 2.67 & 0.026 & 0.812 \\
Crude protein & 658 & 676 & 707 & 726 & 757 & 1.78 & 0.044 & 0.519 \\
Neutral detergent fiber & 502 & 524 & 555 & 579 & 591 & 2.09 & 0.021 & 0.426 \\
\hline
\end{tabular}

Incresing levels of dietary WPSS (g/kg DM).

Probabilities: linear and quadratic effect of WPSS level.

${ }^{\S} \mathrm{NDF}$ intake $(\mathrm{g} / \mathrm{d})=454+0.59$ WPSS $-7.60 \times 10^{-4} \mathrm{WPSS}^{2}$. Maximum point: $389.0 \mathrm{~g} / \mathrm{kg}$ DM.

\section{DISCUSSION}

The antifungal effect of chitosan and derivates have been well documented (CHAPARRO-HERNÁNDEZ et al., 2015; SAEED et al. 2019). Mold and yeasts are undesirable microorganisms of silages that provide silage deterioration, and its inhibition could improve substrate disponibility to bacteria development. Therefore, chitosan has been associated with a positive effect on counts of lactic acid and aerobic bacteria (GANDRA et al., 2016; 2018). On the other hand, anaerobiosis and acidification are considered key points to mold and yeast inhibition (PAHLOW et al., 2003). Homolactic bacteria inoculant anticipates lactic acid bacteria establishment and provides acidification, with other beneficial effects on silage fermentation, especially in low-water soluble carbohydrates materials (OLIVEIRA et al., 2017). Therefore, both additives similarly increased lactic acid in the present study. Additionally, LPPA even showed a more evident negative effect on mold and yeast count, besides both treatments reduced counts of mold and yeast.

Lactic acid bacteria have been commonly used to improve lactic acid fermentation, inhibit harmful epiphytic microbes, and preserve the nutritional value of ensiled material (ARRIOLA et al., 2015; SILVA et al., 2016). According to Muck (2010), lactic acid is the goal end product of silage fermentation, due to more substantial acidification power of lactic (pKa 3.86) than acetic acid ( $\mathrm{pKa}$ 4.76). Therefore, additives reduced silage $\mathrm{pH}$ and fermentative losses of WPSS, in the present study. Oliveira et al. (2017) reported that $\mathrm{LAB}$ inoculation of forages with low WSC, such as alfalfa, tropical and temperate grass silages, reduces $\mathrm{pH}$ and improves DM recovery of silages. According to Driehuis and van Wikselaar (2000), a fast decline of silage $\mathrm{pH}$ reduces the risk of undesirable fermentations by enterobacteria or clostridia, which are mainly aerobic bacteria, and can increase protein degradation. Branched-chain fatty acids (valeric, isovaleric, and isobutyric) are produced from proteolysis and metabolism of branched-chain fatty acids (valine, leucine, and isoleucine; CROWN, MARZE, \& ANTONIEWICZ, 2015). As previously discussed, LPPA probably reduced silage $\mathrm{pH}$ faster than $\mathrm{CHI}$. Therefore, CHI increased $\mathrm{NH}_{3}-\mathrm{N}$ and reduced BCFA, relative to LPPA, due to a higher count of aerobic bacteria.

According to Kung Jr. et al. (2018), some species of clostridia can ferment both carbohydrates and proteins, which are converted into ammonia and biogenic amines. In the present study, additives reduced $\mathrm{NH}_{3}-\mathrm{N}$ and significantly improved the $\mathrm{CP}$ content of the silage. 
The EE uptake during ensiling is near zero, and silage EE concentration improves when fermentation losses increase. Therefore, reduced fermentative losses observed on additive-treated silos resulted in a higher $\mathrm{EE}$ content relative to silos of $\mathrm{CON}$ treatment. The high moisture content (high than $700 \mathrm{~g} / \mathrm{kg}$ ) and elevated $\mathrm{pH}$ of silages favor clostridial fermentation (KUNG Jr. et al., 2018). However, additives decreased DM content of silages. It is known that a higher LAB fermentation rate of silages increases water activity (GREENHILL, 1964), and LAB inoculation is more effective in high moisture silages (DRIEHUIS et al., 1997). The authors agree that this result is linked with increased effluent losses observed on additives-treated silages in the present study. It is interesting to highlight that either effect (on EE and DM) was insufficient to affect additives positive effect on silage DM recovery. In general, additives showed a more significant negative effect on ethanol concentration and reduced fermentative losses, improving DM recovery. Additionally, previously discussed inhibition of secondary fermentation shows an important effect on fermentative losses and DM recovery (BORREANI et al., 2018). Chitosantreated silos showed higher ethanol concentration, which is prone to an increased count of mold and yeast, in relation to LPPA. However, CHI had lower gas fermentative losses than LPPA. Although alcoholic fermentation could be a relevant source of fermentative losses in WSC-rich crops, like sugarcane (PEDROSO et al., 2005), ethanol concentration observed in the present study is remarkably lower than observed in those studies. According to
Borreani et al. (2018), microorganisms other than LAB play a significant role in fermentation DM loss by carbon dioxide synthesis. This is particularly true for yeasts producing ethanol from glucose (e.g., sugarcane silage) or clostridia producing butyrate from lactate or glucose. In legume silages, in which ethanol production is lower important, other secondary fermentation endproducts gain relevance.

Weinberg et al. (1993) studied the LAB inoculation effect on the aerobic stability of wheat, hedysarum, corn, and sorghum silage. These authors associated aerobic deterioration of inoculated silages with high levels of residual WSC and lactic acid, and lack of other organic fatty acids. On the other hand, several studies (GANDRA et al., 2016; DEL VALLE et al., 2018; GANDRA et al., 2018) have been reported a positive effect of chitosan on aerobic stability of silage, by a direct effect on yeast growth. In the present study, additives increased the aerobic stability of silage. However, LPPA showed higher aerobic stability than CHI. Higher short-chain fatty acids content of CHI-treated silos seems to inhibit deterioration and favor stability after aerobic exposure.

When WPSS was added in sheep diets, instead of Cynodon hay, it was observed a linear increase in nutrients digestibility. It highlights the higher nutritional value of WPSS, related to Cynodon hay. Intrinsic characteristics of diet have been considered the restrictive factor for rumen degradation, as a large and nonlimiting enzymatic pool would exist in the rumen (DETMANN et al., 2008). Considering that digestion and passage are concurrent events (NOCEK, 1988), diets with lower NDF digestibility restrict animal feed intake. In the present 
study, besides higher nutrients digestibility, diets with increasing levels of WPSS had lower NDF content. Therefore, it was observed linear positive effects on feed intake. The quadratic effect observed on NDF intake could be considered a consequence of great DM intake depression of CONdiet, and low NDF content of 800-diet.

\section{CONCLUSION}

Chitosan and LPPA addition in WPSS reduces fermentative losses and silage $\mathrm{pH}$, improving crude protein content and aerobic stability of silage. Chitosan reduces fermentative gas losses and shows lower aerobic stability, compared to LPPA. Besides, increasing levels of WPSS in sheep diets linearly increases feed intake and nutrients digestibility.

\section{REFERENCES}

ASSOCIATION OF OFFICIAL ANALYTICAL CHEMISTS. 2000. Official methods of analysis (7th ed). Association of Official Analytical Chemists: Arlington, VA.

ARRIOLA, K.G.; QUEIROZ, O.C.M.; ROMERO, J.J.; CASPER, D.; MUNIZ, E.; HAMIE, J.; ADESOGAN, A.T. Effect of microbial inoculants on the quality and aerobic stability of bermudagrass round-bale haylage. Journal of Dairy Science, v. 98, n. 1, p. 478-485, 2015.

BORREANI, G.; TABACCO, E.; SCHMIDT, R.J.; HOLMES, B.J.; MUCK, R.E. Silage review: Factors affecting dry matter and quality losses in silages Journal of Dairy Science, v. 101, n. 5, p. 3952-3979, 2018.

BRICEÑO, A.G.; MARTÍNEZ, R. Comparison of methods for the detection and enumeration of lactic acid bacteria in yogurt. Archivos Latinoamericanos de Nutrición, v. 45, n. 3, p. 207-212, 1995.

CHAPARRO-HERNÁNDEZ, S.; RUÍZ-CRUZ, S.; MÁRQUEZ-RÍOS, E.; OCAÑOHIGUERA, V.M.; VALENZUELA-LÓPEZ, C.C.; ORNELAS-PAZ， J.J.; DELTOROSÁNCHEZ, C.L. Effect of chitosancarvacrol edible coatings on the quality and shelf life of tilapia (Oreochromis niloticus) fillets stored in ice. Food Science and Technology, v. 35, n. 4, p. 734-741, 2015.

COFFEY, K.P.; GRANADE, G.V.; MOYER, J.L. Nutrient content of silages made from whole-plant soybeans. The Professional Animal Scientist, v. 11, n. 2, p. 74-80, 1995.

CROWN, S.B.; MARZE, N.; ANTONIEWICZ, M.R. Catabolism of branched chain amino acids contributes significantly to synthesis of odd-chain and even-chain fatty acids in 3t3-11 adipocytes. Plos One, v. 10, n. 12, p. e0145850, 2015.

DEL VALLE, T.A.; ZENATTI, T.F.; ANTONIO, G.; CAMPANA, M.; GANDRA， J.R.; ZILIO, E.M.C.; MATTOS, L.F.A.; MORAIS, J.P.G. Effect of chitosan on the preservation quality of sugarcane silage. Grass and Forage Science, v. 73, n. 3, p. 630-638, 2018. 
DING, M.I.; KOIZUMI, H.; SUZUKI, Y. Comparison of three chromatographic systems determination of organic acids in wine. Analytical Sciences, v. 11, p. 239-243, 1995.

DETMANN, E.; PAULINO, M.F.; VALADARES FILHO, S.C. Avaliação nutricional de alimentos ou de dietas? Uma abordagem conceitual. In: Simpósio de produção de gado de corte, 6, 2008, Viçosa. Anais... Viçosa: DZOUFV, 2008. p. 21-52, 2008.

DRIEHUIS, F.; VAN WIKSELAAR, P.G. The occurrence and prevention of ethanol fermentation in high-dry-matter grass silage. Journal of the Science of Food and Agriculture, v. 80, n. 6, p. 711-718, 2000.

DRIEHUIS, F.; VAN WIKSELAAR, P.; VAN VUUREN, A.; SPOELSTRA, S. Effect of a bacterial inoculant on rate of fermentation and chemical composition of high dry matter grass silages. The Journal of Agricultural Science, v. 128, n. 3, p. 323-329, 1997.

DRIEHUIS, F.; OUDE ELFERINK, S.J.W.H.; VAN WIKSELAAR, P.G. Fermentation characteristics and aerobic stability of grass silage inoculated with Lactobacillus buchneri with or without homofermentative lactic acid bacteria. Grass and Forage Science, v. 56, n. 4, p. 330-343, 2001.

FOLDAGER, J. Protein requirement and non-protein nitrogen for high producing cow in early lactation. PhD Diss. Michigan State University, East Lasing, MI, 1977.
GANDRA， J.R.; OLIVEIRA， E.R.; TAKIYA, C.S.; GOES, R.H.T.B.; PAIVA, P.G.; OLIVEIRA, K.M.P.; GANDRA, E.R.S.; ORBACH, N.D.; HARAKI, H.M.C. Chitosan improves the chemical composition, microbiological quality, and aerobic stability of sugarcane silage. Animal Feed Science and Technology, v. 214, p. 44-52, 2016.

GANDRA, J.R.; TAKIYA, C.S.; DEL VALLE, T.A.; OLIVEIRA, E.R.; de GOES, R.H.T.B.; GANDRA E.R.S.; BATISTA, J.D.O.; ARAKI, H.M.C. Soybean whole-plant ensiled with chitosan and lactic acid bacteria: Microorganism counts, fermentative profile, and total losses. Journal of Dairy Science, v. 101, n. 9, p. 78717880, 2018.

GHIZZI, L.G.; DEL VALLE, T.A.; ZILIO, E.M.C.; SAKAMOTO, L.Y.; MARQUES, J.A.; DIAS, M.S.S.; NUNES, A.T.; GHELLER, L.S.; SILVA, T.B.P.; GRIGOLETTO, N.T.S.; TAKIYA, C.S.; SILVA, G.G.; RENNÓ, F. P. Partial replacement of corn silage with soybean silage on nutrient digestibility, ruminal fermentation, and milk fatty acid profile of dairy cows. Animal Feed Science and Technology, v. 264, n. 114526 , 2020.

GREENHILL, W.L. Plant juices in relation to silage fermentation. III. Effect of water activity of juice. Journal of the British Grassland Society, v. 19, n. 3, p. 336-339, 1964.

HOLDEN, L.A. Comparison of methodsof in vitro dry matter digestibility forten feeds. Journal of 
Dairy Science, v. 82 , n. 8 , p. 17911794, 1999.

JAHANZAD, E.; SADEGHPOUR, A.; HOSSEINI, M.B.; BARKER, A.V.; HASHEMI, M.; ZANDVAKILI, O.R. Silage yield and nutritive value of millet-soybean intercrops as influenced by nitrogen application. Agronomy Journal, v. 106, n. 6, p. 1993-2000, 2014.

JOBIM, C.C.; NUSSIO, L.G.; REIS, R.A.; SCHMIDT, P. Methodological advances in evaluation of preserved forage quality. Brazilian Journal of Animal Science, v. 36, p. 101-119, 2007.

KUNG Jr., L; SHAVER, R.D.; GRANT, R.J.; SCHMIDT, R.J. Silage review: Interpretation of chemical, microbial, and organoleptic components of silages Journal of Dairy Science, v. 101, n. 5, p. 4020 4033, 2018.

KUNG， Jr.L; GRIEVE， D.B.; THOMAS, J.W.; HUBER, J.T. Added ammonia or microbial inocula for fermentation and nitrogenous compounds of alfalfa ensiled at various percents of dry matter. Journal of Dairy Science, v. 67, p. 299-306, 1984.

MCDONALD, P.; HENDERSON, A.R.; HERON, S.J.E. The biochemistry of silage (2nd ed) Chalcomb Publications: Marlow, UK, 1991.

MILLER, R.D. Nitric-perchloric acid wet digestion in an open vessel. In KARLA, Y.P. (ed). Handbook of reference methods for plant analysis.
Boca Raton, FL: CRC Press. pp 5762, 1998.

MUCK, R.E. Silage microbiology and its control through additives. Brazilian Journal of Animal Science, v. 39, p. 183-191, 2010.

NI, K.; WANG, F.; ZHU, B.; YANG, J.; ZHOU, G.; PAN, Y.; TAO, Y.; ZHONG, J. Effects of lactic acid bacteria and molasses additives on the microbial community and fermentation quality of soybean silage. Bioresource Technology, v. 238, p. 706-715, 2017.

NOCEK, J.E. In situ and other methods to estimate ruminal protein and energy digestibility: a review. Journal of Dairy Science, v. 71, n. 8, p. 2051-2069, 1988.

NRC. Nutrient requirements of dairy cattle (7th ed) National Academic Press: Washington, DC, USA, 2001. OLIVEIRA, A.S.; WEINBERG, Z.G.; OGUNADE, I.M.; CERVANTES, A.A.P.; ARRIOLA, K.G.; JIANG, Y.; KIM, D.; LI, X.; GONÇALVES, M.C.M.; VYAS, D.; ADESOGAN, A.T. Meta-analysis of effects of homofermentative and facultative heterofermentative lactic acid bacteria inoculation on silage fermentation and aerobic stability, and the performance of dairy cows. Journal of Dairy Science, v. 100, n. 6, p. 4587-4603, 2017.

PAHLOW, G.; MUCK, R.E.; DRIEHUIS, F.; OUDE-ELFERINK, S.J.W.H.; SPOELSTRA, S.F. Microbiology of ensiling. In: BUXTON, D.R.; MUCK, R.E.; 
HARRISON, J.H. (ed.), Silage Science and Technology (1 ed). Madison: American Society of Agronomy. pp 31-94, 2003.

PEDROSO, A.F.; NUSSIO, L.G.; PAZIANI, S.F.; LOURES, D.R.S.; IGARASI, M.S.; COELHO, R.M.; PACKER, I.H.; HORII, J.; GOMES, L.H. Fermentation and epiphytic microflora dynamics in sugar cane silage. Scientia Agricola, v. 62, n. 5, p. 427-432, 2005.

PLAYNE, M.J., MCDONALD, P. The buffering constituents of herbage and of silage. Journal of the Science of Food and Agriculture, v. 17, n. 6, p. 264-268, 1966.

PROTES, V.M.; COSTA, C.; PARIZ, C.M.; CASTILHOS, A.M.; MEIRELLES, P.R.L.; LONGHINI, V.Z.; ROÇA, R.O.; RICARDO, H.A.; MELO, V.F.P. Effects of soybean silage on feeding behavior, performance, and meat quality of lambs. Small Ruminant Research, v. 164, p. 64-69, 2018.

RABIE， C.J.; LIIBBEN, A.; MARAIS, G.J.; JANSEN VAN VUUREN, H. Enumeration of fungi in barley. International Journal of Food Microbiology, v. 35, p. 117127, 1997.

SAEED, A.; HAIDER, A.; ZAHID, S.; KHAN, S.A.; FARYAL, R.; KALEEM， M. In-vitro antifungal efficacy of tissue conditioner-chitosan composites as potential treatment therapy for denture stomatitis. International Journal of Biological
Macromolecules, v. 125, p. 761-766, 2019.

SILVA, V.P.; PEREIRA， O.G.; LEANDRO, E.; DA SILVA, T.; RIBEIRO, K.; MANTOVANI, H.; SANTOS, S. Effects of lactic acid bacteria with bacteriocinogenic potential on the fermentation profile and chemical composition of alfalfa silage in tropical conditions. Journal of Dairy Science, v. 99, n. 3, p. 18951902, 2016

TILLEY, J.M.A., TERRY, R.A. A twostage technique for the in vitro digestion of forage crops. Grass and Forage Science, v. 18, n. 2, p. 104-111, 1963.

VAN SOEST, P.J.; ROBERTSON, J.B.; LEWIS, B.A. Methods for dietary fiber, neutral detergent fiber, non-starch polysaccharides in relation to animal nutrition. Journal of Dairy Science, v. 74, n. 10, p. 3583-3597, 1991.

WEINBERG，Z.G.; ASHBELL， G.; HEN, Y.; AZRIELI, A. The effect of applying lactic acid bacteria at ensiling on aerobic stability of silages. Journal of. Applied Bacteriology, v. 75, n. 6, p. 512-518, 1993. 